\title{
SELF-PROTECTION IN DRY RECYCLE TECHNOLOGIES
}

\author{
W. H. Hannum, D. Wade, G. Stanford \\ ARGONNE NATIONAL LABORATORY \\ 9700 South Cass Avenue \\ Argonne, IL
}



\section{ABSTRACT}

$\log 14003$

In response to the INFCE conclusions, the U.S. undertook development of a new dry fuel cycle. Dry recycle processes have been demonstrated to be feasible. Safeguarding such fuel cycles will be dramatically simpler than the PUREX fuel cycle. At every step of the processes, the materials meet the "spent-fuel standard." The scale is compatible with collocation of power reactors and their recycle facility, eliminating off-site transportation and storage of plutonium-bearing materials. Material diverted either covertly or overtly would be difficult (relative to material available by other means) to process into weapons feedstock.

\section{INTRODUCTION}

An ongoing debate in the U.S. for the past twenty years has explored whether the existence and deliberate expansion of the world stock of plutonium is acceptable. On the one hand, in the 1960s and early 1970s, the projected growth in energy demand led the U.S. to plan for rapid expansion of plutonium stocks through the use of "breeder" reactors $(1,2)$. On the other hand, critics argued that this was unnecessary and dangerous (3).

In 1977, the U.S. unilaterally halted its civilian plutonium separation and purification, and urged others to do the same (4). The intent of this move was to build a major infrastructure barrier between peaceful nuclear power applications and the availability of weapons usable plutonium. Following this, a major international study, the International Nuclear Fuel Cycle Evaluation (INFCE), reviewed proliferation risks in the light of "the urgent need... for nuclear power [to be] widely available" (5). The study concluded that the sensitive points in the nuclear fuel cycle were: 1) stocks of highly enriched uranium (HEU) and separated (pure) plutonium, 2) enrichment facilities and their in-process product, and 3) the facilities for extraction of weapons-usable plutonium from spent nuclear fuel.

The first of these factors has recently been given fresh and urgent significance by nuclear disarmament agreements between the former Soviet Union (FSU) and the U.S. that will result in dismantling weapons containing hundreds of tonnes of weapons-grade nuclear material-plutonium and highly-enriched uranium (6). The second major concern, enrichment capability, is considered by some to now be the area of greatest safeguards vulnerability. Centrifuge technologies are now sufficiently developed and understood that a clandestine enrichment capability could be put together in a reasonably short time and at a cost well within the grasp of a sub-national group.

The major divergence of opinion arises with regard to facilities for processing and treatment of spent fuel, the third point of sensitivity identified by the INFCE study. The traditional separations technolegy (PUREX) is designed to separate plutonium from uranium and thus meets the specific sensitivity criteria identified in the INFCE study. 


\section{Disclaim er}

This report was prepared as an account of work sponsored by an agency of the United States Government. Neither the United States Government nor any agency thereof, nor any of their employees, makes any warranty, express or implied, or assumes any legal liability or responsibility for the accuracy, completeness, or usefulness of any information, apparatus, product, or process disclosed, or represents that its use would not infringe privately owned rights. Reference herein to any specific commercial product, process, or service by trade name, trademark, manufacturer, or otherwise does not necessarily constitute or imply its endorsement, recommendation, or favoring by the United States Government or any agency thereof. The views and opinions of authors expressed herein do not necessarily state or reflect those of the United States Government or any agency thereof. 


\section{DISCLAIMER}

Portions of this document may be illegible in electronic image products. Images are produced from the best available original document. 
Thus, these plants and their resulting product inventories must be subject to particularly rigid safeguards.

Several technologies have been specifically designed to simplify safeguarding. The high levels of radioactivity and the inaccessibility of material characteristic of dry recycle technologies not only simplify safeguarding, but also make that material less attractive as weapons feedstock than other sources that would be available to a nation seeking to undertake a nuclear weapons program.

\section{SAFEGUARDING THE DRY RECYCLE FACILITIES}

Three dry (non-aqueous) recycle technologies have been developed to the point that they deserve evaluation as potential alternates to the traditional PUREX process: the process which was developed as part of the U.S. Integral Fast Reactor (IFR) program (7-9); the AIROX process (10-11); and the Dmitrograd Dry process (DDP) (12-13). Each of these is characterized by a partial removal of fission products and limited segregation among the transuranic contents of the feed stream. The DDP and IFR processes both rely on a selective electrotransport of mixed transuranics, the DDP utilizing oxides and the IFR utilizing a metallic fuel form. The AIROX process is based on a partial separation based on oxide fuels by an oxidation-reduction process; at pyrochemical temperatures (400$600^{\circ} \mathrm{C}$ ), $\mathrm{UO}_{2}$ is converted to granular $\mathrm{U}_{3} \mathrm{O}_{8}$, and the clad and volatile and some semivolatile fission products are driven off. The fuel is then reconverted to $\mathrm{UO}_{2}$ and reenriched by blending or used as is for a CANDU-type reactor. None of these processes are capable of extracting a product from normal burn-up spent fuel that could be used for a nuclear weapon without extensive, complex further radiochemical processing.

The DDP is reportedly (14) the most extensively demonstrated with many thousands of fuel pins having been recycled. The Russian program has already achieved burnup data (as high at $173,000 \mathrm{Mwd} / \mathrm{t}$, or $17.3 \%)$ on more than 11,000 fuel pins $(\sim 300$ fuel assemblies) of vibropacked MOX pins in the BOR-60 experimental and the BN-350 and BN-600 civilian fast-spectrum power reactors. An automated recycle/refabrication plant at Dimitrovgrad has served to prototype a potential commercial facility that could be placed at the site of the proposed two BN-800s. Development programs for waste processing and waste forms are underway.

The basic IFR processes were demonstrated on a practical scale with unirradiated fuel and on a laboratory scale with radioactive materials prior to termination of work on this technology in October 1994.

\section{ATTRACTIVENESS OF MATERIALS FROM DRY RECYCLE}

Dry recycle chemistry yields a plutonium product that is inherently commingled with minor actinides (americium, curium, neptunium), uranium, and certain fission products. The minor actinides provide substantial decay heat and contamination with alpha, beta, gamma, and neutron emitters. Table 1 shows the intrinsic heat deposition rates in typical transuranic-bearing materials, which is due mostly to alpha decay of the minor actinides. The particular case illustrated is for IFR recycle, but the other processes are conceptually similar. The heating rate per gram of heavy metal (including uranium) of the spent fuel is six times that of the unprocessed LWR fuel and coincidentally about five times higher as a processed product. Even with radioactive decay, the heating rate per gram never falls substantially below the rate for the heavy metal in LWR spent fuel. Table 1 also shows

$\log x \times x \quad 2 / 8$ 
that the spontaneous neutron emission rates (neutrons/s) per gram of heavy metal in the spent fuel is three times more than for heavy metal from LWR spent fuel.

The dry recycle chemistry inherently limits fission-product decontamination to a factor no greater than about 1000. A typical product composition of pyroprocessed IFR fuel is compared with a typical PUREX product from the reprocessing of LWR fuel in Table 2. Again, the results will be conceptually similar for other dry processes. From the heavy metal alone, the decay heat and spontaneous neutron emission rates are much higher in the IFR case. In addition to this, the presence of the residual fission products causes the transuranic-containing materials, at every step of the cycle, to be radioactive, enough to be self-protecting due to the gamma radiation from the lanthanides. Figure 1 shows that the radiation level of the material at each step of the process easily meets the self-protection criterion of $1 \mathrm{~W}$ of gamma power $(1 \mathrm{Si} / \mathrm{h}$ at $1 \mathrm{~m}$ ) for the batch quantities of recycle fuels. The PUREX product for LWR recycle is necessarily very low activity. Figure 2 shows the radiation from LWR spent fuel and PUREX recycle fuel; the difference in the radioactivity of the output products is striking.

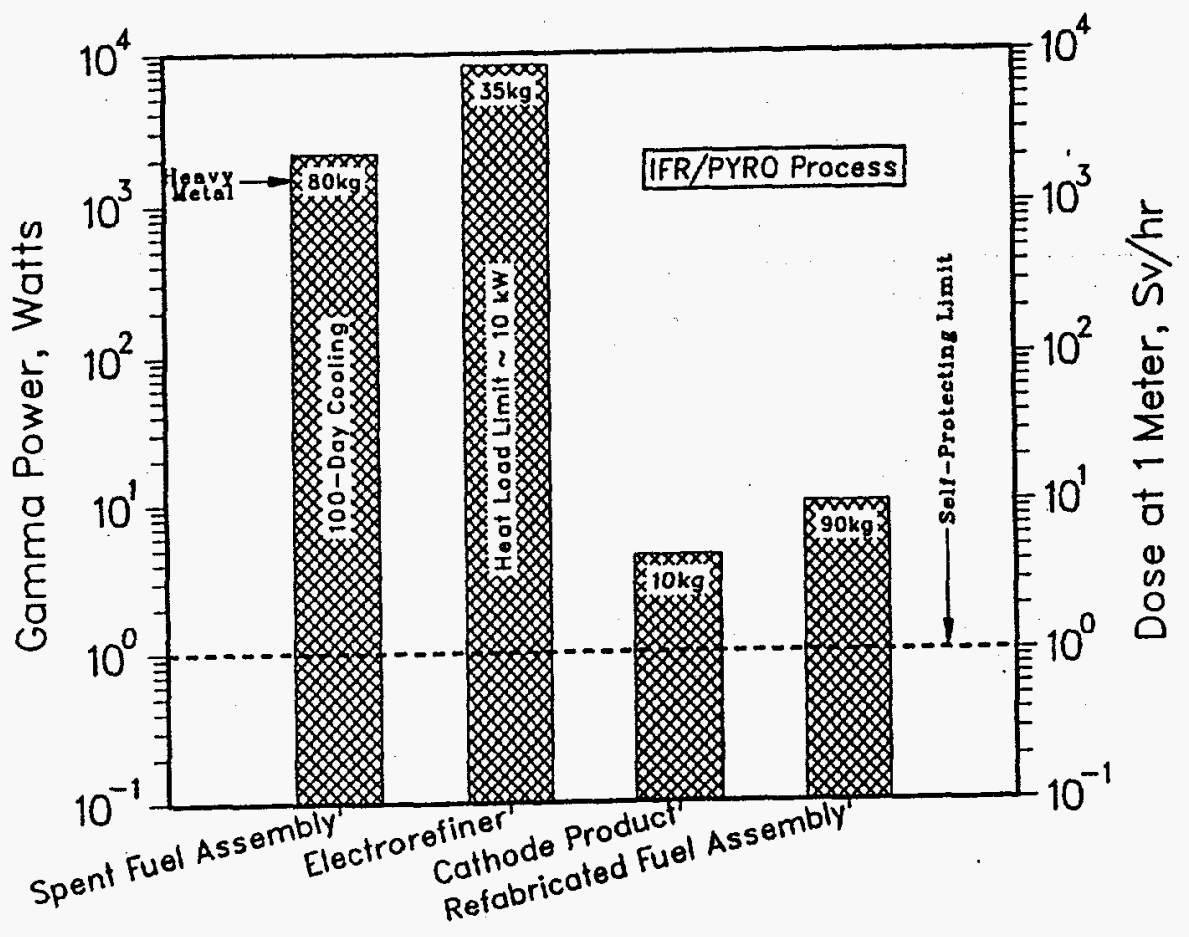

Figure 1. Dry Process Self Protection Levels

U.S. weapon designers have concluded that IFR fuel and recycle materials could not be used to make a nuclear weapon without significant further processing (16).

\section{ATTRACTIVENESS OF MATERIALS AFTER PUREX PROCESSING}

As shown in Table 3, even if dry recycle material were diverted (from any stage of the cycle) and processed in an unsafeguarded PUREX plant, the pure plutonium from PUREX processing of the diverted IFR material would have spontaneous neutron emission rates and heating rates essentially as large (within $30 \%$ ) as those in the pure plutonium that comes from PUREX processing of spent LWR fuel. For weapons purposes, there is no particular significance to the somewhat higher fissile content of the plutonium that is 
typically recycled in a fast reactor system since the yield, yield uncertainty, and manufacturing difficulty are comparable for the two materials. In both cases, further isotopic separation would be needed in order to make highly reliable, efficient nuclear weapons (17).

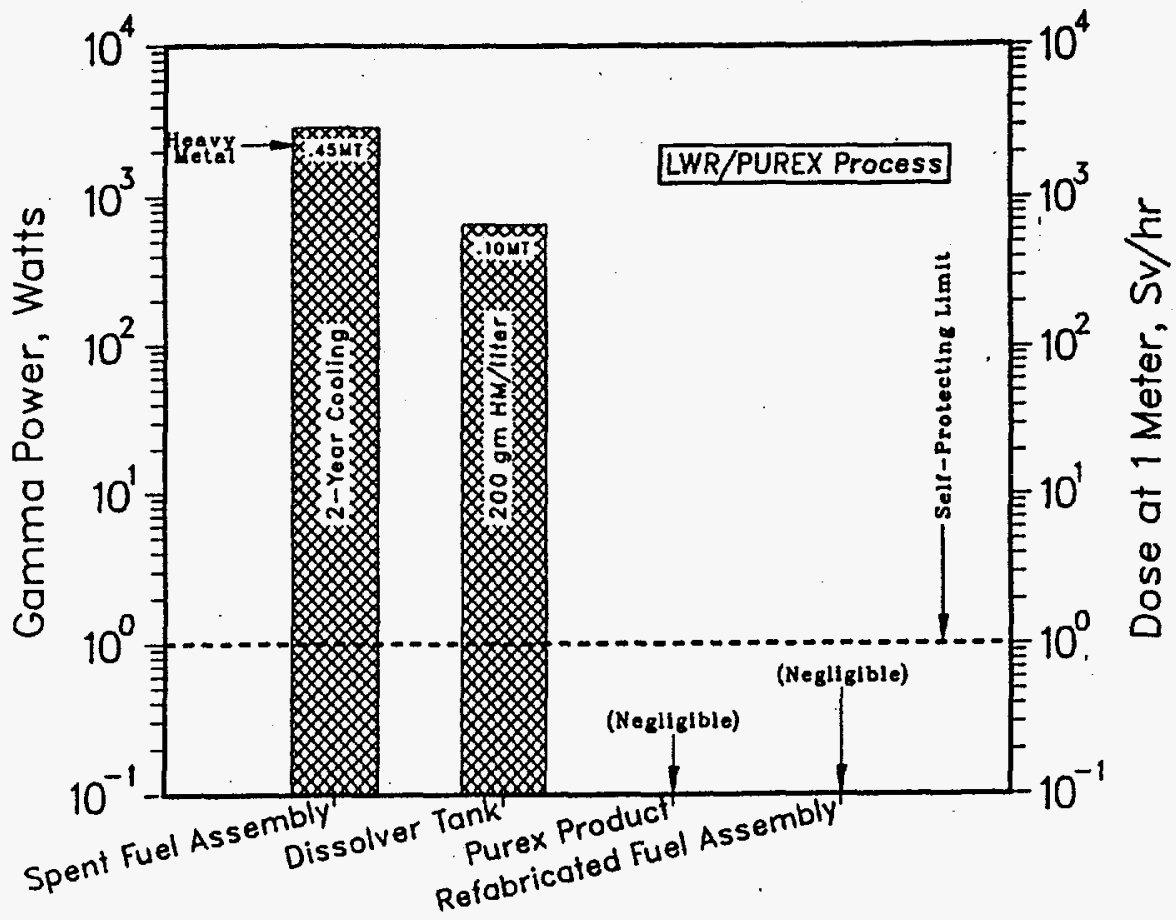

Figure 2. PUREX Process Self Protection Levels

Table I. Decay Heat and Spontaneous Neutron Source Levels

\begin{tabular}{|c|c|c|c|c|c|c|}
\hline \multirow[b]{3}{*}{ Nuclide } & \multicolumn{6}{|c|}{$\begin{array}{c}\text { Spent Fuel at Discharge* } \\
\text { (Normalized to } 1 \mathrm{~kg} \text { HM Basis) }\end{array}$} \\
\hline & \multicolumn{2}{|c|}{$\begin{array}{l}\text { Relative Isotopic Mass } \\
\text { (g/kg HM) }\end{array}$} & \multicolumn{2}{|c|}{$\begin{array}{l}\text { Decay Heat } \\
(\mathrm{W} / \mathrm{kg} \mathrm{HM})\end{array}$} & \multicolumn{2}{|c|}{$\begin{array}{l}\text { Spontaneous Neutrons } \\
\text { neutrons/s/kg HM) }\end{array}$} \\
\hline & LWR & $\underline{\text { IFR }}$ & LWR & IFR & LWR & $\underline{\text { IFR }}$ \\
\hline Total $\mathrm{Pu}$ & 11.23 & 219.9 & 0.10 & 1.43 & 3380 & 47500 \\
\hline $\begin{array}{l}\text { Other } \\
\text { Actindes }\end{array}$ & 1.12 & 3.74 & 2.20 & 10.4 & $1.18 \mathrm{e}+06$ & $3.64 e+06$ \\
\hline Total TRU & 12.35 & 223.7 & 2.30 & 11.8 & $1.19 e+06$ & $3.79 e+06$ \\
\hline Total U & 987.7 & 776.3 & $1.48 \mathrm{e}-03$ & $8.73 e-05$ & $1.23 e+02$ & $4.18 \mathrm{e}+00$ \\
\hline Total HM & 1000.0 & 1000.0 & 2.30 & 11.8 & $1.19 \mathrm{e}+06$ & $3.79 e+06$ \\
\hline
\end{tabular}

*Taken from Hill (15); IFR core is a $1200 \mathrm{MWe}$ fissile self sufficient core with 4 year cycle, 2 year external cycle, $100 \%$ recycle of transuranics (TRU) and $10 \%$ rare earth recycle at $-10 \%$ discharge burnup. 
Table II. Normal Process Product Composition, Decay Heat and Spontaneous Neutron Source Levels*

(PUREX for LWR and PYRO for IFR)

\begin{tabular}{|c|c|c|c|c|c|c|}
\hline \multirow[b]{2}{*}{ Nuclide } & \multicolumn{2}{|c|}{$\begin{array}{l}\text { Relative Isotopic Mass } \\
\ldots \text { (g/kg HM) }\end{array}$} & \multicolumn{2}{|c|}{$\begin{array}{l}\text { Decay Heat } \\
(\mathrm{W} / \mathrm{kg} \mathrm{HM})\end{array}$} & \multicolumn{2}{|c|}{$\begin{array}{c}\text { Spontaneous Neutrons } \\
\text { (neutrons/s/kgHM) }\end{array}$} \\
\hline & LWR & $\underline{\text { IFR }}$ & LWR & IFR & LWR & IFR \\
\hline Total Pu & 1000.0 & 219.9 & 9.62 & 4.30 & $3.01 e+05$ & $1.42 e+05$ \\
\hline $\begin{array}{l}\text { Other } \\
\text { Actinides }\end{array}$ & & 3.74 & & 21.01 & & $9.22 \mathrm{e}+06$ \\
\hline Total TRU & & 223.7 & & 25.31 & & $9.36 e+06$ \\
\hline Total U & & 776.3 & & $1.08 \mathrm{e}-05$ & & $5.17 \mathrm{e}-01$ \\
\hline Total HM & 1000.0 & 1000. & 9.62 & 25.31 & $3.01 \mathrm{e}+05$ & $9.36 e+06$ \\
\hline
\end{tabular}

"PUREX for LWR with 2 y cooling; PYRO for IFR with $100 \mathrm{~d}$ cooling and 2 to 1 ratio for TRU to U.

Table III. Pure Pu Product after PUREX Separation

\begin{tabular}{|c|c|c|c|c|c|c|}
\hline \multirow[b]{2}{*}{ Nuclide } & \multicolumn{2}{|c|}{$\begin{array}{l}\text { Relative Isotopic Mass } \\
-(\mathrm{g} / \mathrm{kg} \mathrm{HM})\end{array}$} & \multicolumn{2}{|c|}{$\begin{array}{l}\text { Decay Heat } \\
(\mathrm{W} / \mathrm{kg} \mathrm{HM})\end{array}$} & \multicolumn{2}{|c|}{$\begin{array}{c}\text { Spontaneous Neutrons } \\
\text { (neutrons/s kg HM) }\end{array}$} \\
\hline & LWR & IFR & $\underline{L W R}$ & IFR & $\underline{L W R}$ & $\underline{\text { IFR }}$ \\
\hline Pu-236 & 0.000265 & 0.0000623 & 0.00305 & 0.00108 & 0 & 0 \\
\hline Pu-238 & 9.98 & 6.38 & 6.33 & 3.63 & 26400 & 16800 \\
\hline Pu-239 & 553 & 760 & 1.07 & 1.44 & 12 & 16.6 \\
\hline $\mathrm{Pu}-240$ & 221 & 203 & 1.54 & 1.39 & 201000 & 185000 \\
\hline Pu241 & 173 & 21.7 & 0.671 & 0.0902 & 7.06 & 1.02 \\
\hline $\mathrm{Pu}-242$ & $\underline{0.432}$ & $\underline{8.64+00}$ & $\underline{0.00504}$ & $\underline{0.000994}$ & 74000 & 14900 \\
\hline Total $\mathrm{Pu}$ & 1000 & 1000 & 9.62 & 6.56 & 301000 & 217000 \\
\hline
\end{tabular}

With modern technology, experts maintain that any plutonium composition could be used to produce a nuclear explosion, but it is evident that higher content of higher isotopes makes it exceedingly difficult to make a bomb. Much has been made of the U.S. tests of a nuclear weapon produced from "reactor grade" plutonium. While the actual composition of that material remains classified, the time at which those tests were performed suggests that the material was closer to "weapons grade" than to isotopic composition that would now be obtained from a commercial fuel cycle.

The possibility of loading a U-238 assembly into a reactor to make isotopically pure ${ }^{239} \mathrm{Pu}$ adds nothing to the proliferation potential that already exists with LWRs. LWR fuel assemblies are enriched in ${ }^{235} U$ only to 3 or $4 \%$ versus the less than $1 \%$ enrichment in a fast reactor blanket. A nation deciding to abrogate its nonproliferation agreements has the option of short-irradiation cycles for making isotopically pure plutonium in any power 
reactor; a denial of inspector access, seizure of assemblies, and transport to an unsafeguarded PUREX process facility are all required before the plutonium can be recovered.

\section{DETECTION AND DIVERSION}

Dry recycle materials are intrinsically unattractive targets for diversion; physical protection is easier to provide for these fuels than for many other plutonium inventories; and inspection and accountancy techniques currently being developed and demonstrated promise to be straightforward because of the discrete (item accountancy) of the process steps.

Major safeguards against covert diversion include material control and accountancy (MC\&A) and detectability. Highly enriched uranium and ${ }^{239} \mathrm{Pu}$ are comparatively difficult to detect in that active interrogation techniques are required. Detectability of irradiated materials or of reactor grade plutonium is very high due to the emitted radiation. In an overt diversion scenario, adequate shielding, confinement, and isolation are credible, but this would be very difficult in a covert scenario given access to modern detection capabilities.

Consider the diversion of a spent fuel assembly from an LWR versus that from a dry recycle facility. In both cases, the diverter would have to abrogate treaties, throw out inspectors, seize and transport a highly-radioactive assembly, and process it in an unsafeguarded PUREX facility. Independent of where in the dry cycle the material had been seized, the subsequent conversion would have to take place in a nonstandard PUREX process. Diversion from a DDR or IFR-type cycle would be particularly difficult because these fuels contain a higher fraction of fissile material, so that the front-end PUREX dissolver tank must be redesigned for more stringent criticality limits, or the input material must be blended down to a much lower fissile content. Also, the shorter cooling time used in the dry cycle leads to higher decay-heat loads and greater heat-removal requirements in the shipping casks and processing equipment, unless the proliferator is willing to wait -- which would ensure timely warning. The higher radiation levels (due to the shorter cooling time and higher burnup) are more damaging to the organic chemical reagents used in PUREX reprocessing, so that a special PUREX plant for handling diverted dry recycle materials would require the reagent to be replaced more frequently. In addition, for IFR type fuels, there are additional protections associated with pyrophoricity and the incompatibility of the $\mathrm{Zr}$ alloying material with traditional solvents $(18,19)$.

Thus, the dry recycle processes have features that intrinsically avoid segregation of plutonium from uranium, minor actinides, and fission products, assuring that the dry recycle materials at every stage of the closed cycle are no more attractive for diversion than LWR spent fuel -- in most cases much less attractive.

\section{ACCESSIBILITY BARRIERS}

It is characteristic of dry recycle processes that they utilize relatively small scale process equipment. There is no major penalty in scaling the process to correspond with a power station site, thus minimizing transportation and facilitating physical security and access control. Transportation is generally a sensitive phase in any security system. On-site, such material will always be contained either inside the reactor or in the highly shielded, 
remotely operated, inert-atmosphere enclosure of transport casks or the hot cells in the recycle facility.

It has been argued (20) that acquisition by a developing country of hot cell for remote handling of radioactive materials "may be a key proliferation issue" because "the equipment and materials used in PUREX processing would require the type of heavy shielding offered by the hot cell of a dry recycle system." This argument is specious. Modification of a system for purifying plutonium would severely interrupt normal operation and be detectable with any inspection regime. A declared, safeguarded dry recycle facility is not of concern because the conversion time following renunciation of safeguarding obligations would be extensive.

\section{CONTROL AND ACCOUNTANCY}

The basis for nuclear material control and accountancy (MCA) in dry recycle technologies is different from that required by a PUREX-type process (21). MCA is facilitated by the fact that the special nuclear material remains highly contaminated throughout the fuel cycle. Item accounting is used for fuel passing between the reactor and the collocated recycle facility. Activities in which the form and composition of the fuel are changed can be done only within the highly shielded, remotely operated recycle hot cell, which has an inert gas atmosphere and a limited number of access and transfer ports.

The batch-type recycle readily supports near-real-time MCA. Movement of material is controlled remotely with movements and weights recorded in real time by the MCA system. When material is moved from one process step to the next, it is moved as a discrete mass in a labeled container and weighed before shipment from one station and after receipt at the next station. There are no transfers involving movement of liquid through lines nor operations in which transfer valves are used. Waste and scrap also are handled as discrete, tracked, and weighed items.

For the recycle steps that involve holdup (the electrorefiner), MCA techniques appropriate to the highly-radioactive dissolver stage of conventional (PUREX) reprocessing apply. No step in the cycle requires the highly-stringent MCA and safeguards procedures that are required for the parts of the conventional PUREX cycle [including operations to fabricate mixed oxide (MOX) fuel] that involve purified plutonium.

\section{REFERENCES}

(1) AEC (1962) Civilian Nuclear Power: A Report to the President, U. S. Atomic Energy Commission.

(2) AEC (1967) Civilian Nuclear Power. The 1967 Supplement to the 1962 Report to the President, U.S. Atomic Energy Commission.

(3) Cochran, T. B., Speth, J. G. and Tamplin, A. R. (1975) Bypassing the Breeder: A Report on Misplaced Federal Energy Priorities, Natural Resources Defense Council, Washington, D.C.

(4) Carter, President Jimmy (1977), Energy Policy Address.

(5) INFCE (1980) International Nuclear Fuel Cycle Evaluation, International Atomic Energy Agency Report INFCE/PC/2/9.

(6) Willett, L. R. (1993) Disposition of Excess. Plutonium, Transactions of the American Nuclear Society $69,88$. 
(7) Till, C. E. and Chang, Y. I. (1986) The Integral Fast Reactor Concept, Proceeding American Power Conference 48, 688, Chicago, IL, 14-16 April.

(8) Till, C. E. and Chang, Y. I. (1988) The Integral Fast Reactor, Advances in Nuclear Science and Technology 20, 127.

(9) Till, C. E. (1994) Energy Over the Centuries: The IFR Options, Managing the Plutonium Surplus: Applications and Options Conference, The Royal Institute of International Affairs, 24-25 January.

(10) Feinroth, Guon, J. and Majumdar, D., An Overview of the AIROX Process and its Potential for Nuclear Fuel Recycle, Proceedings of the International Conference and Technology Exhibition on Future Nuclear Systems: Emerging Fuel Cycles and Waste Disposal Options, p. 709 Seattle, WA, 12-17 September.

(11) Allison, C. M., (1993) Neutronics and Fuel Behavior of Airox-Processed Fuel Recycled Into Light Water Reactors, Proceedings of the International Conference and Technology Exhibition on Future Nuclear Systems: Emerging Fuel Cycles and Waste Disposal Options, p. 709 Seattle, WA, 12-17 September.

(12) Skiba, O. V., Savochkin, Yu. P., Bychkov, A. V., Porodnov, P. T., Babikov, L. G. and Vavilov, $S$. K. (1993b) Technology of Pyroelectrochemical Reprocessing and Production of Nuclear Fuel, Proceedings of the International Conference on Future Nuclear Systems: Emerging Fuel Cycles and Waste Disposal Options p. 1344, Seattle, WA, 12-17 September.

(13) Bychkov, A. V., Vavilov, S. K., Porodnov, P. T. and Skiba, O. V. (1993) Pyroelectrochemical Reprocessing of Irradiated Uranium-Plutonium Oxide Fuel for Fast Reactors, Proceedings of the International Conference on Future Nuclear Systems: Emerging Fuel Cycles and Waste Disposal Options, p. 1351 Seattle, WA, 12-17 September.

(14) Skiba, O. V., Mayorshin, A. A., Porodnov, P. T. and Keruchenko, S. S. (1991) Possible Ways of Fast Reactor Fuel Cycle Development on the Basis of U-Pu Oxide Fuel, Proceedings of the International Conference on Fast Reactors and Related Fuel Cycles, p.6.12-2, Kyoto, Japan, 28 October-1 November.

(I5) Hill, R. N., Wade, D. C., Fujita, E. K. and Khalil, H. S. (1990) Physics Studies of Higher Actinide Consumption in an LMR, International Conference on the Physics of Reactors I, 83, Marseille, France, 23-27 April.

(16) Goldman, D. J. (1994) Some Implications of Using IFR High-Transuranic Plutonium in a Proliferant Nuclear Weapons Program, Lawrence Livermore National Laboratory Document COTDU-94-0199.

(17) DeVolpi, A. (1986) Fissile Materials and Nuclear Weapons Proliferation, Annual Review of Nuclear Particle Science $36,83$.

(18) DOE (1992) Explosion Hazards of Uranium-Zirconium Alloys, Office of Nuclear Safety Report DOE/NS-0008.

(19) Larson, R. P., Shor, R. S., Feder, H. M. and Flikkema, D. S. (1954) A Study of the Explosive Properties of Uranium-Zirconium Alloys, Argonne National Laboratory Report ANL-5135.

(20) OTA (1994) Technical Options for the Advanced Liquid Metal Reactor, U.S. Congress, Office of Technology Assessment.

(21) Wymer, R. G., Bengelsdorf, H. D., Choppin, G. R., Coops, M. S., Guon, J., Pillary, K. K. S. and Williams, J. D. (1992) An Assessment of the Proliferation Potential and International Implications of the Integral Fast Reactor, Martin Marietta Report K/ITP511 . 